\title{
MYCORRHIZAL PROPAGULE PERSISTENCE IN A SUCCESSION OF CEREALS IN A DISTURBED AND UNDISTURBED ANDISOL FERTILIZED WITH TWO NITROGEN SOURCES
}

\author{
Pablo Cornejo ${ }^{1 *}$, Rosa Rubio ${ }^{1}$, and Fernando Borie ${ }^{1}$
}

\begin{abstract}
Arbuscular mycorrhizal fungi (AMF) form symbiosis with plant roots, improving its establishment, nutrition, and tolerance to adverse soil conditions. In annual crop rotations, some aspects such as the type of $\mathrm{N}$ fertilizer and tillage system used can affect the AMF propagule density and its functionality in the following crop. To analyze the effect of the agronomic practices previously mentioned on the persistence and density of AMF propagules, a study in a succession of cereals was carried out. For this, soil previously cropped with wheat (Triticum aestivum L.) and fertilized with urea $\left(\mathrm{NH}_{4}^{+}\right)$or sodium nitrate $\left(\mathrm{NO}_{3}{ }^{-}\right)$was disturbed in each case by simulating conventional tillage (CT) or maintained without disturbing, simulating no-tillage (NT). It was then cultivated with oat (Avena sativa L.) using the same $\mathrm{N}$ sources. Higher densities of AMF active mycelium and colonized root length in the NT soil were observed (76 and 497\% higher than in $\mathrm{CT}$ soil, respectively, $\mathrm{P}<0.001$ ). Moreover, $\mathrm{NT}+\mathrm{NO}_{3}{ }^{-}$interaction produced a higher density of AMF spores ( $75 \%$ higher than in the rest of the treatments, $\mathrm{P}<0.05$ ), although showing a decrease in comparison with the previous wheat crop. These results suggest that $\mathrm{N}$ source and tillage system interact to influence persistence and density of AMF propagules, an important aspect to consider in acidic soils intended for annual crops.
\end{abstract}

Key words: arbuscular mycorrhiza, mycorrhizal propagules, soil disturbing, soil pH, wheat-oat succession.

\section{INTRODUCTION}

The volcanic soils of Southern Chile, mainly Ultisols and Andisols, show a natural tendency to acidity due to its particular mineral composition with high allophane and high organic matter content (Zunino and Borie, 1985). These soils cover an area over $5 \times 10^{6}$ ha, mainly used in annual cereal and legume rotations. Conventional tillage in these soils with plowing and harrowing have been widely practiced, altering soil conditions, microorganism activity and growth, and nutrient dynamics (Alvear et al., 2005; Borie et al., 2006).

It is well-known that soil microbiota plays a fundamental role improving productivity and stability of natural and agricultural ecosystems (Jeffries and Barea, 2001; Barea et al., 2005). Within this microbiota, stand out the arbuscular mycorrhizal fungi (AMF), which establish

${ }^{1}$ Universidad de La Frontera, Departamento de Ciencias Químicas, Casilla 54-D, Temuco, Chile. *Corresponding author (pcornejo@ufro.cl). Received: 11 March 2008.

Accepted: 24 August 2008. a mutualistic symbiosis called arbuscular mycorrhiza, with most of terrestrial plants. In this symbiosis, AMF benefit nutrient absorption and translocation to plant, particularly those less mobile in the soil, such as phosphate, ammonium, and numerous micronutrients, due to the extension of the radical system that represents the fungal hyphae in the soil (Clark et al., 1999; Barea, 2000; Cornejo et al., 2008a). In turn, the fungus receives carbonaceous compounds from plant photosynthesis (Pfeffer et al., 1999; Bago et al., 2002). It has been observed that plant production is significantly increased in mycorrhized plants compared to non-mycorrhized plants in acidic soils (Clark et al., 1999). By the above, adequate management of native AMF populations in these soils is an important aspect to consider in sustainable agricultural systems.

Several studies have demonstrated that the functionality of mycorrhizal symbiosis in agrosystems is affected by practices such as the previous crop in the rotation, type of fertilizer used, and tillage system, influencing persistence and density of AMF propagules remaining in the soil (Borie and Rubio, 1999; Rubio 
et al., 2003; Borie et al., 2006; Cornejo et al., 2007; 2008b). However, among the most relevant aspects to be taken into account in acidic soils is the emphasis on the type of $\mathrm{N}$ fertilizer used, because the nitrate $\left(\mathrm{NO}_{3}{ }^{-}\right)$and ammonium $\left(\mathrm{NH}_{4}^{+}\right)$ions have a considerable effect on the variations of rhizospheric $\mathrm{pH}$, owing these ions are the most abundant, most absorbed, and most accumulated by the plant (Gerendás et al., 1997; Cornejo et al., 2008a). Moreover, the $\mathrm{NH}_{4}^{+}$nitrification process generates $\mathrm{H}^{+}$among its products, so its use as a fertilizer can promote severe acidification processes, particularly in naturally acidic soils like those of volcanic origin in Southern Chile (Campillo and Rodríguez, 1984; Martens, 2001; Chu et al., 2005). Related to the aforementioned, it is known that AMF extraradical hyphae can absorb different $\mathrm{N}$ sources, both ionic and some organic forms, so that they can contribute significantly in the variations of mycorrhizospheric pH (Bago et al., 1996; Bago and Azcón-Aguilar, 1997; Hawkins et al., 2000; LópezPedrosa et al., 2006; Cornejo et al., 2008b).

In addition, the tillage system used can have a considerable effect on soil microbiota. In general terms, it has been observed that no-tillage or the use of conservation tillage systems benefit the size, diversity, and activity of soil microbial populations (Oehl et al., 2004; Alvear et al., 2005), and in the case of AMF, it would be related to greater root colonization, propagule density, and communities diversity of this type of fungi (Borie et al., 2000; 2006; Jansa et al., 2002). However, the joint effect that the type of $\mathrm{N}$ source and tillage system has on AMF propagule densities in annual rotation systems in volcanic soils from Southern Chile has not been studied.

Therefore, the aim of this study was to analyze, under controlled greenhouse conditions, the effect of contrasting $\mathrm{N}$ sources applied as fertilizers and soil alteration on persistence and density of AMF propagules in a succession of cereals, simulating a crop rotation in an Andisol. Assuming that arbuscular mycorrhizal symbiosis plays an important role in plant growth and nutrition, it is necessary to know the basis for selecting agronomic management alternatives that increase persistence, density and activity of AMF propagules naturally present in volcanic soils from Southern Chile.

\section{MATERIALS AND METHODS}

\section{Experimental design}

A factorial design $2 \times 2$ full randomized was used, including two $\mathrm{N}$ sources $\left(\mathrm{NO}_{3}{ }^{-}\right.$and $\left.\mathrm{NH}_{4}{ }^{+}\right)$, each of which simulated tillage systems with (conventional tillage, $\mathrm{CT}$ ) and without (zero tillage, NT) soil sieving in the experimental units. Hereafter, this simulation factor of the different tillage systems will be referred as soil alteration.
In each case, four replicates were used for each established combination $(n=16)$.

\section{Soil characteristics}

The soil used was obtained in a field intended for annual crops in the commune of Vilcún $\left(38^{\circ} 41^{\prime} \mathrm{S}\right.$; 72²4' W; 180 m.a.s.1.), La Araucanía Region, Chile. Some initial characteristics of this Andisol are shown in Table 1 (Temuco family, Vilcún series; mesic, Entyc Dystrandept). Soil was collected from a of $5-25 \mathrm{~cm}$ depth, air-dried, sieved at $5 \mathrm{~mm}$, fertilized with $0.063 \mathrm{~g} \mathrm{P} \mathrm{kg}^{-1}$ as pulverized triple super phosphate and $0.063 \mathrm{~g} \mathrm{~K} \mathrm{~kg}^{-1}$ as $\mathrm{KCl}$ in solution, equivalent to a $100 \mathrm{~kg} \mathrm{ha}^{-1}$ dose of each nutrient, similar to those used by farmers for cereal crops in these same soils. Sixteen $1 \mathrm{~L}$ pots with $800 \mathrm{~g}$ of this soil were prepared. Subsequently, wheat (Triticum aestivum L., cv. Otto-Baer) plants were established and fertilized with $0.126 \mathrm{~g} \mathrm{~N} \mathrm{~kg}^{-1}$ (30\% in Zadocks 11 and $70 \%$ in Zadocks 31; Zadocks et al., 1974), equivalent to a $200 \mathrm{~kg} \mathrm{~N} \mathrm{ha}^{-1}$ dose, using $\mathrm{CO}\left(\mathrm{NH}_{2}\right)_{2}$ as a source of $\mathrm{NH}_{4}{ }^{+}$in half of the experimental units, and $\mathrm{NaNO}_{3}$ as a source of $\mathrm{NO}_{3}^{-}$in the rest. At the end of this crop (dry grain, Zadocks 99), wheat plants were harvested and after 3 months, the soil of four experimental units fertilized with each $\mathrm{N}$ source was disturbed by sieving at $5 \mathrm{~mm}$, simulating CT. Then $\mathrm{pH}$ and AMF propagule density (spores, total and active hyphae, and colonized root length) were determined in the sieved experimental units in order to know the initial value of the soil parameters at the time of establishing the second cereal in the designed rotation simulation (Table 2).

\section{Plant material}

Oat (Avena sativa L. cv. Urano-INIA) was used as a second AMF host in the simulated cereal rotation. Oat seeds were sterilized with a $2 \% \mathrm{w} / \mathrm{v}$ Chloramine- $\mathrm{T}$ $\left(\mathrm{CH}_{3} \mathrm{C}_{6} \mathrm{H}_{4} \mathrm{SO}_{2} \mathrm{~N}(\mathrm{Cl}) \mathrm{Na} \times \mathrm{H}_{2} \mathrm{O}\right)$ solution for $3 \mathrm{~min}$ and were rinsed thoroughly with $\mathrm{dH}_{2} \mathrm{O}$. Seeds were pregerminated on sterile tissue paper moistened with $\mathrm{dH}_{2} \mathrm{O}$

Table 1. Selected chemical characteristics and arbuscular mycorrhizal fungi (AMF) propagule density of the soil used in this study.

\begin{tabular}{lc}
\hline Available $\mathrm{P}($ Olsen$), \mathrm{mg} \mathrm{kg}^{-1}$ & 4.00 \\
$\mathrm{pH}\left(\mathrm{H}_{2} \mathrm{O}\right)$ & 5.42 \\
Organic matter, $\mathrm{g} \mathrm{kg}^{-1}$ & 180 \\
$\mathrm{CEC}, \mathrm{cmol}(+) \mathrm{kg}^{-1}$ & 11.33 \\
$\mathrm{Al}$ saturation, \% & 0.61 \\
AMF spores in $100 \mathrm{~g}$ & 406 \\
Total hyphal AMF density, $\mathrm{m} \mathrm{g}^{-1}$ & 8.50 \\
Active hyphal AMF density, $\mathrm{m} \mathrm{g}^{-1}$ & 4.34
\end{tabular}

CEC: cation exchange capacity. 
Table 2. Soil pH and arbuscular mycorrhizal fungi (AMF) propagule density 3 months post-harvest of wheat (Triticum aestivum cv. Otto-Baer) crop fertilized with two $\mathrm{N}$ sources $\left(\mathrm{NO}_{3}^{-}\right.$and $\left.\mathrm{NH}_{4}{ }^{+}\right)$.

\begin{tabular}{|c|c|c|c|c|c|}
\hline \multirow[b]{2}{*}{ N source } & \multirow[b]{2}{*}{$\mathrm{pH}\left(\mathrm{H}_{2} \mathrm{O}\right)$} & \multirow[b]{2}{*}{ AMF spores in $100 \mathrm{~g}$} & \multicolumn{2}{|c|}{ Hyphal AMF $\left(\mathrm{m} \mathrm{g}^{-1}\right)$} & \multirow{2}{*}{$\begin{array}{l}\text { Colonized root } \\
\left(\mathrm{m} \mathrm{pot}^{-1}\right)\end{array}$} \\
\hline & & & Total & Active & \\
\hline $\mathrm{NH}_{4}^{+}$ & $5.18(0.01)$ & 955 (97) & $12.4(2.66)$ & $7.64(1.38)$ & $40.2(2.76)$ \\
\hline $\mathrm{NO}_{3}^{-}$ & $5.49(0.02)$ & $1775(457)$ & $12.9(3.23)$ & $6.07(0.80)$ & $30.3(2.19)$ \\
\hline
\end{tabular}

Standard error is shown in parentheses.

and after 7 days, two seedlings of each experimental unit were established with homogeneous growth of 5-6 cm leaf length and 4-5 cm radical length.

\section{Crop conditions}

Plants, both wheat and oat, grew under greenhouse conditions at $25 \pm 3 / 15 \pm 3{ }^{\circ} \mathrm{C}$ day/night temperatures, 16:8 h light:dark photoperiod, and relative humidity of $80-90 \%$. Pots were watered manually with distilled water according to plant needs during the experiment (determined by pot weight). Every 2 weeks, $10 \mathrm{~mL}$ of nutritive solution were added (Johnson et al., 1996) without $\mathrm{P}$ and $\mathrm{N}$, to compensate the possible microelement deficiencies due to limited soil volume. Nitrogen fertilizer was applied in two portions: at the establishment of the oat plants (30\% in Zadocks 11) and at the half tillering stage (70\% in Zadocks 22-24), to complete $0.063 \mathrm{~g} \mathrm{~N} \mathrm{~kg}^{-1}$, which represents a dose of $100 \mathrm{~kg} \mathrm{~N} \mathrm{ha}^{-1}$. The $\mathrm{N}$ fertilizers were the same used for the previous wheat crop.

\section{Measurements}

Evaluations were carried out at the beginning of anthesis (Zadocks 60, 150 days after sowing). Roots and shoots were dried at $65{ }^{\circ} \mathrm{C}$ for $48 \mathrm{~h}$ in a forced-air oven (UIM 400, Memmert GMBH + Co., Schwabach, Germany), and weighed. Before drying the roots, a portion was separated to determine the proportion of AMF colonized root (Giovanetti and Mosse, 1980) after clearing with a $10 \% \mathrm{w} / \mathrm{v} \mathrm{KOH}$ solution and staining with trypan blue (Phillips and Hayman, 1970). Root length was measured by gridline intersect method (Tennant, 1975). Total extraradical mycorrhizal hyphae were determined by the method described by Borie et al. (2000) and the metabolically active hyphae by detecting their dehydrogenase activity (Kabir et al., 1997). Total density of both types of hyphae was quantified by the Newman (1966) line intersect method after collection in a nitrocellulose filter with $0.45 \mu \mathrm{m}$ pore size (White Gridded HAWG, Millipore, Bedford, Massachusetts, USA). The AMF spores were separated from the soil by wet sieving and decanting in a 70\% w/v sucrose solution (Gerdemann and Nicholson, 1963), and were quantified with a stereo magnifying glass with a 30-50 magnification. Soil $\mathrm{pH}$ was measured in a soil: $\mathrm{dH}_{2} \mathrm{O}$ mix $(2: 5 \mathrm{w} / \mathrm{v})$.

\section{Statistical analysis}

The effect of soil alteration, $\mathrm{N}$ source, and their interaction were determined by means of a two-way ANOVA. Means were compared by the orthogonal contrast test. Data not meeting assumption for ANOVA were transformed, but the results are shown in their original measurement scale. Principal component analysis (PCA) was carried out to establish the relationship between distinct response variables, the extracted principal components (PC), and the established treatments. A non-hierarchical cluster analysis with the farthest-neighbor method based on the factors obtained was used to determine the similarity between the different experimental units. In all cases the SPSS software v. 10.0 (SPSS Inc., Chicago, Illinois, USA) was used. Statistical significance was determined at $\mathrm{P}<0.05$.

\section{RESULTS AND DISCUSSION}

Both soil alteration and $\mathrm{N}$ source separately showed a strong influence on most of the studied variables (Table 3). Nevertheless, the interaction of these factors only influenced some variables $(\mathrm{pH}$, root biomass, and AMF spore density). In particular, soil alteration showed a greater influence on changes on AMF propagules, especially root colonization and hyphae density (total and active), as well as on the root biomass production, the shoot/root ratio $(\mathrm{S} / \mathrm{R})$, and root length. On the other hand, the $\mathrm{N}$ source showed a strong influence on the variation of soil $\mathrm{pH}$ which reached a difference of 0.8 units between $\mathrm{CT}+\mathrm{NH}_{4}{ }^{+}$and $\mathrm{NT}+\mathrm{NO}_{3}{ }^{-}$treatments (Figure 1).

The use of $\mathrm{NO}_{3}{ }^{-}$as $\mathrm{N}$ source generated a $\mathrm{pH}$ increase in this study, which would be due to the extrusion of $\mathrm{OH}^{-}$to the rhizosphere associated with the absorption of $\mathrm{NO}_{3}{ }^{-}$to maintain the radical electroneutrality. On the other hand, in treatments where $\mathrm{NH}_{4}{ }^{+}$was used, lower $\mathrm{pH}$ values were observed which would be produced by $\mathrm{H}^{+}$extrusion in the rhizosphere (Marschner, 1995; Logan et al., 1999). In addition, the predictable rhizosphere acidification due 
Table 3. $F$-values and probability of significance for the main effects and factor interaction for the variables analyzed by means of a two-way ANOVA.

\begin{tabular}{lccc}
\hline Experimental variable & Soil alteration $(\mathbf{A})$ & N source $(\mathbf{N})$ & A x N \\
\hline $\mathrm{pH}\left(\mathrm{H}_{2} \mathrm{O}\right)$ & $118.0^{* * *}$ & $588.7^{* * *}$ & $36.8^{* * *}$ \\
Biomass $\mathrm{S}^{1}, \mathrm{~g}$ & $0.7 \mathrm{~ns}$ & $5.6^{*}$ & $1.7 \mathrm{~ns}$ \\
Biomass R, g & $41.2^{* * *}$ & $8.8^{*}$ & $20.4^{* *}$ \\
$\mathrm{~S}: \mathrm{R}$ ratio & $59.2^{* * *}$ & $4.4^{*}$ & $5.2^{*}$ \\
Total root, $\mathrm{m}$ & $35.4^{* * *}$ & $2.4 \mathrm{~ns}$ & $9.7^{*}$ \\
Colonized root, $\mathrm{m}$ & $61.5^{* * *}$ & $0.0 \mathrm{~ns}$ & $1.9 \mathrm{~ns}$ \\
Colonized root, \% & $231.5^{* * *}$ & $42.5^{* * *}$ & $4.4^{*}$ \\
Total hyphae, $\mathrm{m} \mathrm{g}^{-1}$ & $21.8^{* *}$ & $17.1^{* *}$ & $0.5 \mathrm{~ns}$ \\
Active hyphae, $\mathrm{m} \mathrm{g}^{-1}$ & $47.4^{* * *}$ & $5.7^{*}$ & $3.4 \mathrm{~ns}$ \\
Active hyphae, $\%$ & $0.0 \mathrm{~ns}$ & $3.3 \mathrm{~ns}$ & $4.0 \mathrm{~ns}$ \\
AMF spores $100 \mathrm{~g}^{-1}$ & $1.4 \mathrm{~ns}$ & $3.6 \mathrm{~ns}$ & $4.4^{*}$ \\
\hline
\end{tabular}

${ }^{*} \mathrm{P}<0.05,{ }^{* *} \mathrm{P}<0.01, * * * \mathrm{P}<0.001$, ns: not significant

${ }^{1} \mathrm{~S}$ : shoot; R: root; AMF: arbuscular mycorrhizal fungi.

to nitrification of $\mathrm{NH}_{4}^{+}$, that can represent an important source of acidity in volcanic soils, must be consider (Campillo and Rodríguez, 1984; Martens, 2001; Cornejo et al., 2007). This aspect is especially relevant when choising the type of $\mathrm{N}$ fertilizer to be used, particularly in soils that naturally tend to be acidic.

Moreover, NT use also produced a $\mathrm{pH}$ increase, observing an additive effect of both factors ( $\mathrm{N}$ source and soil alteration) in the $\mathrm{NT}+\mathrm{NO}_{3}{ }^{-}$combination. Observed alkalinization with $\mathrm{NO}_{3}{ }^{-}$, though significantly different in CT treatments, was less than that observed in NT treatments. In particular, the ratio and absolute length of

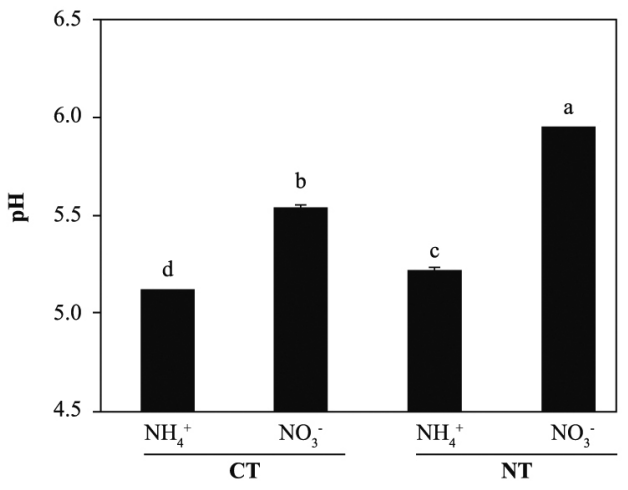

Bars represent mean \pm standard error. Different letters indicate differences according to orthogonal contrasts $(\mathrm{P}<0.05 ; n=16)$.

Figure 1. Soil pH in an oat (Avena sativa cv. Urano-INIA) crop fertilized with two $\mathrm{N}$ sources $\left(\mathrm{NO}_{3}{ }^{-}\right.$and $\left.\mathrm{NH}_{4}{ }^{+}\right)$ simulating conventional tillage (CT) and no-tillage (NT). colonized root were 2 to 4 times higher in the NT treatments than in the CT (Figure 2), suggesting a strong influence of established arbuscular mycorrhiza in the rhizospheric $\mathrm{pH}$ modification. In addition, $\mathrm{pH}$ also increased with $\mathrm{NO}_{3}{ }^{-}$as $\mathrm{N}$ source in disturbed and undisturbed soils, which could be due to the greater AMF spore density at the end of the preceding wheat crop in treatments with $\mathrm{NO}_{3}{ }^{-}$as $\mathrm{N}$-source (Table 2). These would have functioned as an increased source of mycorrhizal inoculum, allowing an earlier and more intense colonization in the oat plants fertilized with $\mathrm{NO}_{3}{ }^{-}$as $\mathrm{N}$ source. This fact can be especially relevant in annual rotation systems like those commonly used in extensive areas of the Central-Southern Chile, since the $\mathrm{N}$ source, besides directly influencing the number of propagules remaining in the soil at the end of the crop, would determine inoculum potential of AMF present in the soil for the next crop in the rotation (Cornejo et al., 2007; 2008b). In a similar study by de Varennes and Goss (2007), it was concluded that the greatest efficiency of tripartite symbiosis among native AMF, rhizobia, and legumes was due to the greater AMF colonization rates which were reached more prematurely in undisturbed than in disturbed soils. Regarding the aforementioned, numerous studies suggest that conventional tillage, disturbing the soil, generates a decrease in the infectiveness of the AMF mycelium by destroying the hyphae network in the soil (see Kabir, 2005 for a review), which supposedly occurred in this study when simulating conventional tillage by sieving.

The use of $\mathrm{NO}_{3}{ }^{-}$as $\mathrm{N}$ source would generate adequate conditions for greater growth of the fungal structures, especially in soils with acidic characteristics. In this sense, Cornejo et al. (2007) studied the effect of $\mathrm{NO}_{3}{ }^{-}$and $\mathrm{NH}_{4}{ }^{+}$ 
on the development of Glomus etunicatum in a wheat crop growing in an Andisol under greenhouse conditions, observing that the use of $\mathrm{NO}_{3}^{-}$sequentially promoted greater root colonization in vegetative growth stages of the crop, greater density of metabolically active hyphae at harvest time, and greater density of fungal spores 3 months after harvest. In this study, during the growth stage of oat Zadocks 60 , similar results to those obtained by Cornejo et al. (2007) were observed in the same growth stage for wheat, both in mycorrhizal colonization and production of extraradical hyphae (Figure 3). In turn, results obtained in this study suggest that variations in $\mathrm{pH}$ and mycorrhization were produced by the addition and/ or feedback of the effects of a greater AM functionality (or at least a greater colonization intensity), and the effect of $\mathrm{NO}_{3}{ }^{-}$as $\mathrm{N}$ source in the rhizospheric alkalinization by absorption both by the root and fungal hyphae (Bago et al., 1996; Bago and Azcón-Aguilar, 1997). Therefore, this effect would be dependent on both the N source applied, the mycorrhizal status of the plant, and the magnitude of its mycorrhizal colonization (Vaast and Zasoski, 1992; Bago et al., 1996; Bago and Azcón-Aguilar, 1997).

Density of AMF extraradical hyphae was greater in NT than in CT treatments, particularly the active hyphae density, although this difference was not of the magnitude
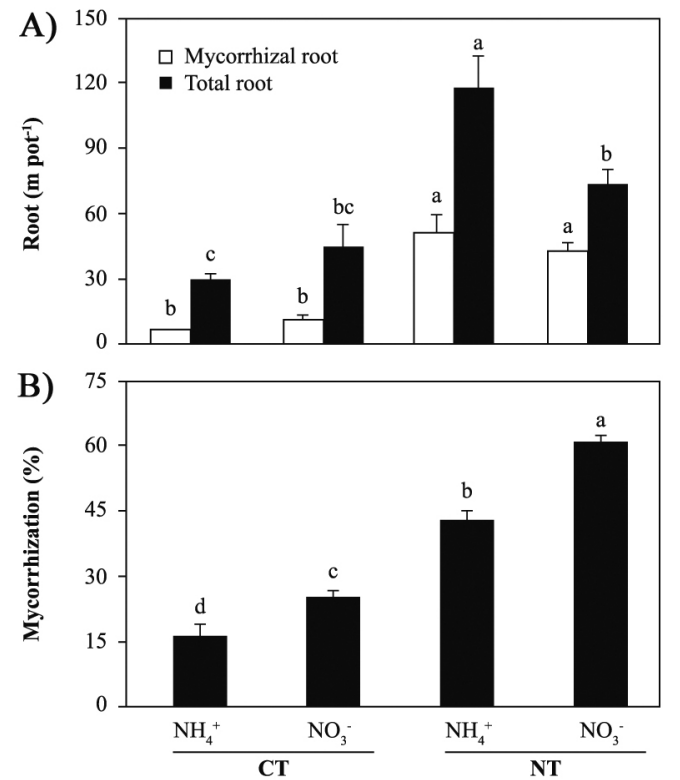

Bars represent mean \pm standard error. Different letters indicate differences according to orthogonal contrasts $(\mathrm{P}<0.05 ; n=16)$.

Figure 2. (A) Total and mycorrhizal root length and (B) mycorrhization in an oat (Avena sativa cv. UranoINIA) crop fertilized with two $\mathrm{N}$ sources $\left(\mathrm{NO}_{3}^{-}\right.$and $\mathrm{NH}_{4}{ }^{+}$) simulating conventional tillage (CT) and notillage (NT). observed in mycorrhization or mycorrhizal root length (Figure 3). These results agree with those found by Borie $e t$ al. (2006) who studied the effect of distinct tillage systems in Ultisols in the Central-Southern Chile, finding greater densities of AMF mycelium and radical colonization in crops cultivated with conservation systems (no-tillage and reduced tillage) than those cultivated in a conventional way.

On the other hand, the use of $\mathrm{NH}_{4}^{+}$as $\mathrm{N}$ source was associated with a greater density of total AMF hyphae than with $\mathrm{NO}_{3}^{-}$, suggesting the presence of a compensation mechanism by AMF to capture this ion that is less mobile in the soil, but for which high-affinity transporters have been described in this type of fungi (López-Pedrosa et al., 2006). In the particular case of the $\mathrm{NT}+\mathrm{NO}_{3}{ }^{-}$treatment the greater density of active hyphae would be related to a greater level of radical colonization, a preliminary step before extraradical production of hyphae. Furthermore, disturbing the soil would reduce the ratio of metabolically active hyphae in the soil (Figure 3). This is particularly evident in the $\mathrm{CT}+\mathrm{NH}_{4}{ }^{+}$treatment respect to the NT treatments that jointly showed $10 \%$ more activity.
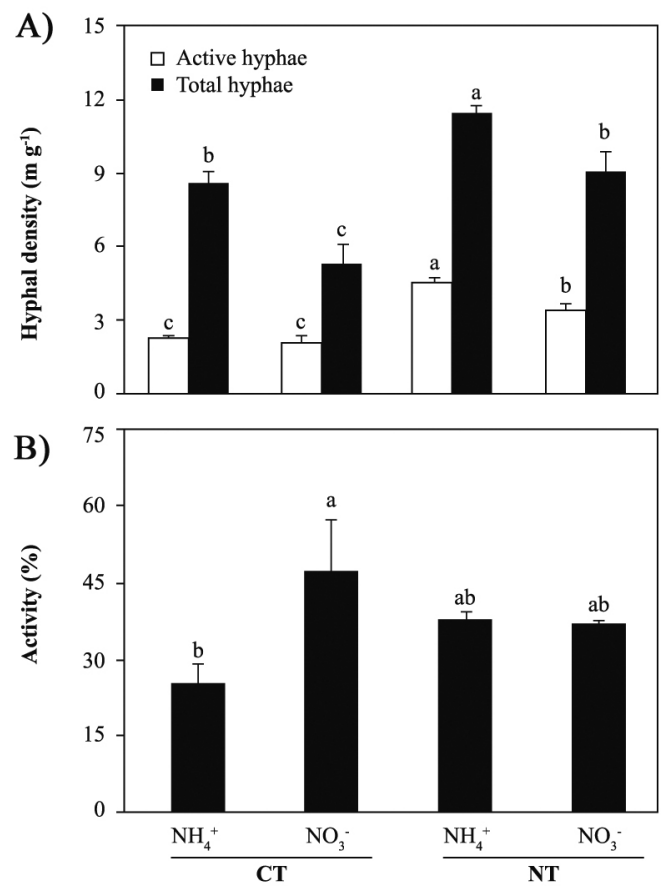

Bars represent mean \pm standard error. Different letters indicate differences according to orthogonal contrasts $(\mathrm{P}<0.05 ; n=16)$.

Figure 3. (A) Extraradical hyphal density (total and metabolically active) and (B) ratio of active arbuscular mycorrhizal fungi (AMF) hyphae in an oat (Avena sativa cv. Urano-INIA) crop fertilized with two $\mathrm{N}$ sources $\left(\mathrm{NO}_{3}^{-}\right.$and $\left.\mathrm{NH}_{4}^{+}\right)$simulating conventional tillage (CT) and no-tillage (NT). 
Relative to the AMF spore production, the $\mathrm{NT}+\mathrm{NO}_{3}^{-}$ treatment showed a density 62 to $99 \%$ greater than the other treatments (Figure 4). This result shows that both $\mathrm{NO}_{3}{ }^{-}$as $\mathrm{N}$ source and the tillage systems that disturb less the soil can promote the density of an important biotic component in view of maintaining a long-term presence of AMF propagules. This spore density increase is related to $\mathrm{pH}$ increase, situation already observed in previous studies under similar conditions (Rubio et al., 2003; Cornejo et al., 2007; 2008b). In this study, differences in spore density were also found in intermediate growth stages (Z60) which differs from the observed by Cornejo et al. (2007), where these differences, with contrasting $\mathrm{N}$ sources, were found in wheat postharvest. This corroborates the manifestation of an additive effect between $\mathrm{NO}_{3}{ }^{-}$as $\mathrm{N}$ source and $\mathrm{NT}$ on the density of AMF propagules, since the fungus growth and symbiotic development would be accelerated, and be expressed in earlier stages of crops growing in acidic soils.

Other observations by the authors of this study have shown direct and significant relationships between plant biomass production and spore density in the soil at postharvest (Cornejo et al., 2008b). Nevertheless, the biomass levels obtained in this study were similar (Figure 5), so the increase of spore density in the $\mathrm{NT}+\mathrm{NO}_{3}$ treatment would basically be due to the improvement of the soil characteristics with $\mathrm{NO}_{3}{ }^{-}$, and the greater density of functional AMF propagules.

Shoot biomass production did not show any differences except in the $\mathrm{CT}+\mathrm{NH}_{4}{ }^{+}$treatment when compared to the $\mathrm{CT}+\mathrm{NO}_{3}{ }^{-}$treatment. Differences of a greater magnitude were observed in root biomass production, showing CT treatments greater values than NT treatments. Compared to the root length (Figure 2), it can be concluded that this greater radical biomass production was associated with root swelling in CT treatment, probably related with the lower observed colonization. These results generate a greater S:R ratio in NT treatments, showing greater biomass production efficiency in the shoot of these treatments, precisely those that showed more colonization and greater active hyphae density. Related to these results, previous studies show that mycorrhized plants demonstrate inhibition of radical growth due to the AMF hyphae, as a whole, acts as a complementary radical system compensating many root functions (Barea, 2000).

Principal components analysis, followed by a nonhierarchical cluster analysis allowed the formation of highly homogeneous groups (Figure 6). The experimental design was strongly adjusted to this type of analysis, explaining PC 1 a $57.6 \%$ and PC 2 a $42.4 \%$ of the total variance, respectively. Principal component 1 was significantly correlated with $\mathrm{pH}$, total and colonized root length, and biomass production, while PC 2 was

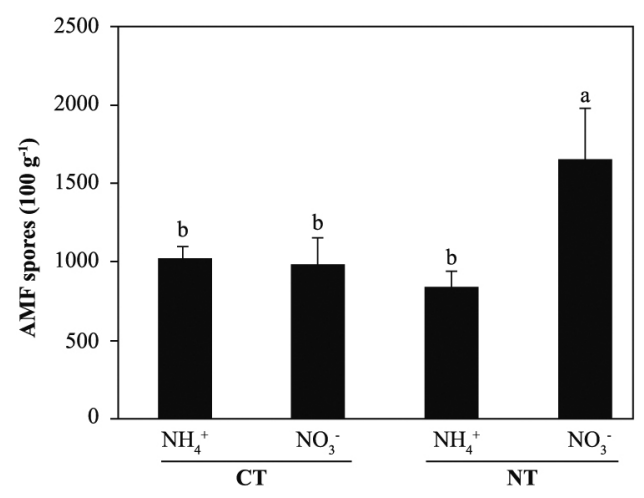

Bars represent mean \pm standard error. Different letters indicate differences according to orthogonal contrasts $(\mathrm{P}<0.05 ; n=16)$.

Figure 4. Arbuscular mycorrhizal fungi (AMF) spore density in an oat (Avena sativa cv. Urano-INIA) crop fertilized with two $\mathrm{N}$ sources $\left(\mathrm{NO}_{3}{ }^{-}\right.$and $\left.\mathrm{NH}_{4}{ }^{+}\right)$ simulating conventional tillage (CT) and no-tillage (NT).
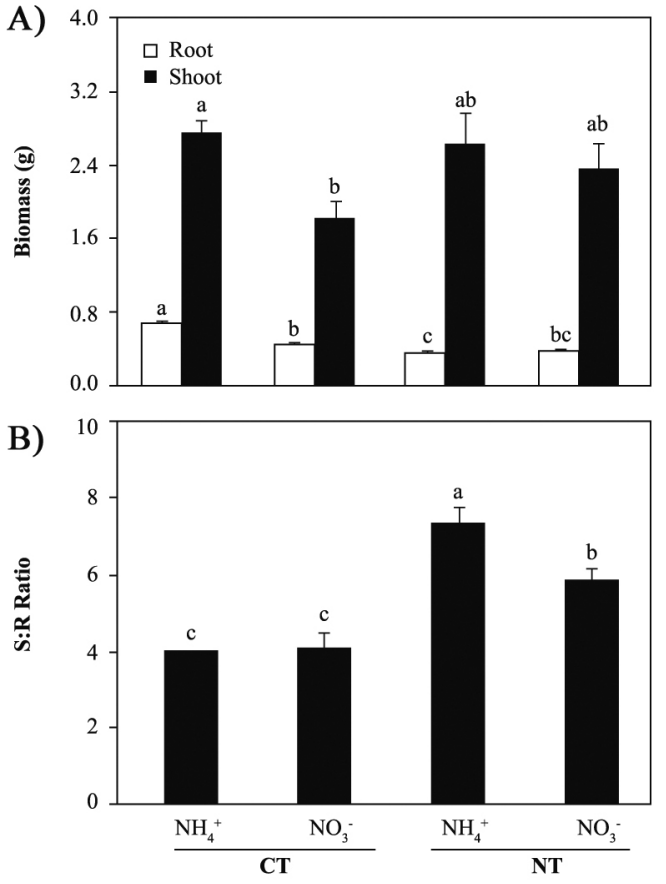

Bars represent mean \pm standard error. Different letters indicate differences according to orthogonal contrasts $(\mathrm{P}<0.05 ; n=16)$.

Figure 5. (A) Plant biomass and (B) shoot:root ratio (S:R) in an oat (Avena sativa cv. Urano-INIA) crop fertilized with two $\mathrm{N}$ sources $\left(\mathrm{NO}_{3}^{-}\right.$and $\left.\mathrm{NH}_{4}^{+}\right)$simulating conventional tillage (CT) and no-tillage (NT). 


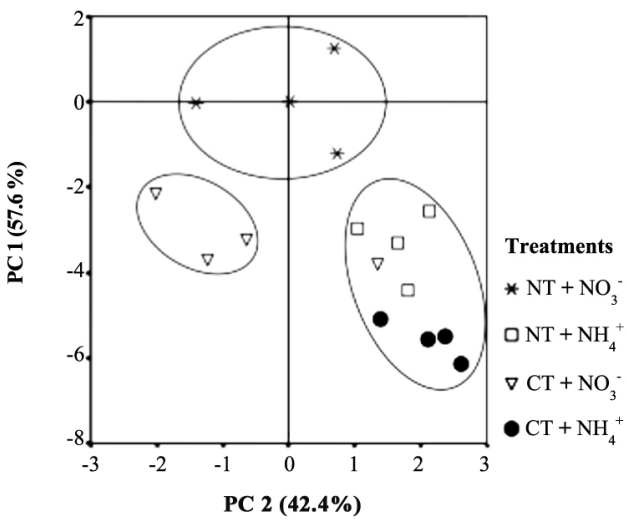

NT: no tillage; CT: conventional tillage.

Figure 6. Scatter plot of experimental units in accordance with the principal components (PC) obtained from the analyzed variables. Ellipses include experimental units with similar behavior (in accordance with nonhierarchical cluster analysis) and should be understood as a visual aid for discrimination of groups.

correlated with the density of total and active hyphae. Among the groups formed after the non-hierarchical cluster analysis, highlight the $\mathrm{NT}+\mathrm{NO}_{3}{ }^{-}$treatment with a high incidence in PC 1 and intermediate values in PC 2 , representing a group with high biomass production, high mycorrhizal propagule density, and a considerable $\mathrm{pH}$ increase. Treatments which used $\mathrm{NH}_{4}{ }^{+}$as $\mathrm{N}$ source formed another group that showed a greater hyphal density associated with a high incidence in PC 2, but heterogeneous with respect to the other studied variables. The $\mathrm{CT}+\mathrm{NO}_{3}{ }^{-}$treatment showed intermediate values on PC 1 associated with an intermediate biomass production and AMF propagule densities that would represent, in this particular case, the effect of $\mathrm{NO}_{3}^{-}$, but without the added beneficial effect of NT.

It is worth noting that variations in the values of the different studied variables, compared to their initial values (after wheat postharvest, Table 1), show the additive effect of $\mathrm{NO}_{3}{ }^{-}$used as $\mathrm{N}$ source and undisturbed soil, especially emphasized in the $\mathrm{pH}$, that registered an increase of 0.46 units in the $\mathrm{NT}+\mathrm{NO}_{3}{ }^{-}$treatment (Table 4). This suggests a positive interaction relative to the use of ammonium $\mathrm{N}$ sources and conventional tillage systems that could be evident in rotation programs in the short- or mediumterm. In the case of AMF hyphae and spores, virtually in all the analyzed situations, a decrease was observed, probably due to the early use of these propagules in the first colonization stages (spore germination and radical colonization), before the stages of structure resistance formation, temporarily close to plant senescence (Cornejo et al., 2007). In spite of the aforementioned, it can be observed that the decrease related to the initial values was more moderate in NT than in CT treatments, especially in the cases in which $\mathrm{NO}_{3}{ }^{-}$was used. This greater propagule persistence and density is of special agroecological interest when the available alternatives to manage AMF populations naturally found in volcanic soils in Southern Chile are considered.

\section{CONCLUSIONS}

It can be concluded that the $\mathrm{N}$ source used as fertilizer and the application of practices which disturbing or nondisturbing the soil in crop successions of mycorrhizable species, such as those commonly established in volcanic soils in Southern Chile, have a strong effect on the persistence and density of AMF propagules, and $\mathrm{pH}$ changes in the soil. In particular, the use of $\mathrm{NO}_{3}{ }^{-}$is associated to the widely studied effect of rhizospheric alkalinization, as well as to a greater density of AMF propagules that would facilitate early mycorrhizal colonization in the plant species of the next crop in the succession. On the other hand, conservation tillage systems, such as the one simulated in this study, generate a considerable increase in mycorrhizal colonization and AMF propagule density, as well as increased $\mathrm{pH}$ in the soil, with an additional effect to the one observed with $\mathrm{NO}_{3}{ }^{-}$as $\mathrm{N}$ source. These aspects can be of a special agronomic

Table 4. Variation of some studied parameters by effect of soil alteration and $N$ source relative to the initial values determined at establishment of oat (Avena sativa cv. Urano-INIA) crop.

\begin{tabular}{|c|c|c|c|c|c|}
\hline \multirow{2}{*}{$\begin{array}{l}\text { Soil } \\
\text { alteration }\end{array}$} & \multirow[b]{2}{*}{ N source } & \multirow[b]{2}{*}{ pH } & \multirow[b]{2}{*}{ Spores in $100 \mathrm{~g}$} & \multicolumn{2}{|c|}{ Hyphal AMF $\left(\mathrm{m} \mathrm{g}^{-1}\right)$} \\
\hline & & & & Total & Active \\
\hline \multirow[t]{2}{*}{$\mathrm{CT}$} & $\mathrm{NH}_{4}^{+}$ & $-0.07(0.01) \mathrm{c}$ & $57(101) \mathrm{a}$ & $-3.77(0.50) b$ & $-5.47(0.16) c$ \\
\hline & $\mathrm{NO}_{3}^{-}$ & $0.06(0.01) b$ & $-802(177) b$ & $-7.83(0.99) \mathrm{c}$ & $-4.04(0.27) b$ \\
\hline \multirow[t]{2}{*}{ NT } & $\mathrm{NH}_{4}^{+}$ & $0.04(0.02) b$ & $-127(108) \mathrm{a}$ & $-0.95(0.31) \mathrm{a}$ & $-3.27(0.27) a b$ \\
\hline & $\mathrm{NO}_{3}^{-}$ & $0.46(0.01) \mathrm{a}$ & $-130(335) \mathrm{a}$ & $-3.95(0.89) b$ & $-2.77(0.26) \mathrm{a}$ \\
\hline
\end{tabular}

Means followed by the same letter in a column are not significantly different according to the orthogonal contrast test $(\mathrm{P}<0.05 ; n=16)$. Standard error is shown in parentheses.

AMF: arbuscular mycorrhizal fungi; CT: conventional tillage; NT: no-tillage. 
relevance since fertilization and tillage system represent two aspects of crop management with the greatest impact on the productivity and stability of agroecosystems.

\section{ACKNOWLEDGEMENTS}

This study was financed by FONDECYT Project 1990756, from Comisión Nacional de Investigación Científica y Tecnológica, CONICYT, Chile.

\section{RESUMEN}

Persistencia de propágulos micorrícicos en una sucesión de cereales en un Andisol disturbado y no disturbado, fertilizado con dos fuentes de nitrógeno. Los hongos micorrícico-arbusculares (AMF) forman simbiosis con las raíces de las plantas, favoreciendo su establecimiento, nutrición y tolerancia a condiciones adversas del suelo. En rotaciones de cultivos anuales algunos aspectos como el tipo de fertilizante nitrogenado utilizado y el sistema de labranza pueden afectar la densidad de propágulos de AMF y su funcionalidad en el cultivo siguiente. Para analizar el efecto de las prácticas agronómicas previamente mencionadas sobre la persistencia y densidad de los propágulos de AMF, se realizó un estudio en microcosmos simulando una rotación de cereales. Para esto, suelo previamente cultivado con trigo (Triticum aestivum L.) y fertilizado con urea $\left(\mathrm{NH}_{4}{ }^{+}\right)$ o nitrato de sodio $\left(\mathrm{NO}_{3}^{-}\right)$fue, en cada caso, disturbado simulando una labranza convencional (CT) o mantenido sin disturbar simulando cero labranza (NT) y cultivado con avena (Avena sativa L.), utilizando las mismas fuentes de N. Se observaron mayores densidades de micelio activo de AMF y longitudes de raíz colonizada en el suelo NT (76 y 497\% mayor que en suelo CT, respectivamente; $\mathrm{P}<$ 0,001). Por otra parte, la interacción $\mathrm{NT}+\mathrm{NO}_{3}^{-}$produjo una mayor densidad de esporas de AMF (75\% mayor que en el resto de los tratamientos, $\mathrm{P}<0,05)$, aunque mostrando una disminución respecto del cultivo previo de trigo. Estos resultados sugieren que la fuente de $\mathrm{N}$ y el sistema de labranza influyen interactivamente sobre la persistencia y densidad de propágulos de AMF, aspecto importante de considerar en suelos ácidos destinados a cultivos anuales.

Palabras clave: alteración del suelo, micorriza arbuscular, pH del suelo, propágulos micorrícicos, sucesión trigoavena.

\section{LITERATURE CITED}

Alvear, M., A. Rosas, J.L. Rouanet, and F. Borie. 2005. Effects of three soil tillage systems on some biological activities in an Ultisol from southern Chile. Soil Tillage Res. 82:195-202.

Bago, B., and C. Azcón-Aguilar. 1997. Changes in the rhizospheric $\mathrm{pH}$ induced by arbuscular mycorrhiza formation in onion (Allium cepa L.). Z. Pflanzenernah. Bodenk. 160:333-339.

Bago, B., P.E. Pfeffer, W. Zipfel, P. Lammers, and Y. Shachar-Hill. 2002. Tracking metabolism and imaging transport in arbuscular mycorrhizal fungi. Plant Soil 244:189-197.

Bago, B., H. Vierheilig, Y. Piché, and C. Azcón-Aguilar. 1996. Nitrate depletion and $\mathrm{pH}$ changes induced by the extraradical mycelium of the arbuscular mycorrhizal fungus Glomus intraradices grown in monoxenic culture. New Phytol. 13:273-280.

Barea, J.M. 2000. Rhizosphere and mycorrhiza of field crops. p. 110-125 In Toutant, J., E. Balazs, E. Galante, J. Lynch, J. Schepers, D. Werner, and P. Werry. (eds.) Biological Resource Management: Connecting Science and Policy (OECD). INRA editions and Springer-Verlag, Heidelberg, Germany.

Barea, J.M., M.J. Pozo, R. Azcón, and C. Azcón-Aguilar. 2005. Microbial co-operation in the rhizosphere. J. Exp. Bot. 56:1761-1778.

Borie, F., and R. Rubio. 1999. Effects of arbuscular mycorrhizae and liming on growth and mineral acquisition of aluminium-tolerant and aluminiumsensitive barley cultivars. J. Plant Nutr. 22:121-137.

Borie, F., R. Rubio, A. Morales, and C. Castillo. 2000. Relationships between arbuscular mycorrhizal hyphal density and glomalin production with physical and chemical characteristics of soil under no-tillage. Rev. Chil. Hist. Nat. 73:749-756.

Borie, F., R. Rubio, J.L. Rouanet, A. Morales, G. Borie, and C. Rojas. 2006. Effects of tillage systems on soil characteristics, glomalin and mycorrhizal propagules in a Chilean Ultisol. Soil Tillage Res. 88:253-261.

Campillo, R., y J. Rodríguez. 1984. Efecto acidificante de las transformaciones de la urea en dos Andisoles de la región de Los Lagos. Agric. Téc. (Chile) 44:131-138.

Chu, H.Y., Y. Hosen, K. Yagi, K. Okada, and O. Ito. 2005. Soil microbial biomass and activities in a Japanese Andisol as affected by controlled release and application depth of urea. Biol. Fertil. Soils 42:89-96.

Clark, R.B., S.K. Zeto, and R.W. Zobel. 1999. Arbuscular mycorrhizal fungal isolate effectiveness on growth and root colonization of Panicum virgatum in acidic soil. Soil Biol. Biochem. 31:1757-1763. 
Cornejo, P., F. Borie, R. Rubio, and R. Azcón. 2007. Influence of nitrogen source on the viability, functionality and persistence of Glomus etunicatum fungal propagules in an Andisol. Appl. Soil Ecol. 35:423-431.

Cornejo, P., R. Rubio, and F. Borie. 2008b. Effect of nitrogen source on some rhizospheric properties and persistence of mycorrhizal fungal propagules in an Andisol. Chil. J. Agric. Res. 68:119-127.

Cornejo, P., R. Rubio, C. Castillo, R. Azcón, and F. Borie. 2008a. Mycorrhizal effectiveness on wheat nutrient acquisition in an acidic soil from southern Chile as affected by nitrogen sources. J. Plant Nutr. 31:15551569.

de Varennes, A., and M.J. Goss. 2007. The tripartite symbiosis between legumes, rhizobia and indigenous mycorrhizal fungi is more efficient in undisturbed soil. Soil Biol. Biochem. 39:2603-2607.

Gerdemann, J., and T. Nicholson. 1963. Spores of mycorrhizal endogone species extracted from soil by wet sieving. Trans. Brit. Mycol. Soc. 46:234-235.

Gerendás, J., Z. Zhu, R. Bendixen, R. Ratcliffe, and B. Sattelmacher. 1997. Physiological and biochemical processes related to ammonium toxicity in higher plants. Z. Pflanzenernah. Bodenk. 160:239-251.

Giovanetti, M., and B. Mosse. 1980. An evaluation of techniques for measuring vesicular-arbuscular mycorrhizal infection in roots. New Phytol. 84:489500.

Hawkins, H.J., A. Johansen, and E. George. 2000. Uptake and transport of organic and inorganic nitrogen by arbuscular mycorrhizal fungi. Plant Soil 226:275-285.

Jansa, J., A. Mozafar, T. Anken, R. Ruh, I.R. Sanders, and E. Frossard. 2002. Diversity and structure of AMF communities as affected by tillage in a temperate soil. Mycorrhiza 12:225-234.

Jeffries, P., and J.M. Barea. 2001. Arbuscular mycorrhiza a key component of sustainable plant-soil ecosystems. p. 95-113. In Hock, B. (ed.) The mycota. Volume IX. Fungal associations. Springer-Verlag, Berlin, Germany.

Johnson, J.F., C.P. Vance, and D.L. Allan. 1996. Phosphorus deficiency in Lupinus albus. Altered lateral root development and enhanced expression of phosphoenolpyruvate carboxylase. Plant Physiol. 112:31-41.

Kabir, Z. 2005. Tillage or no-tillage: Impact on Mycorrhizae. Can. J. Plant. Sci. 85:23-29.

Kabir, Z., I.P. O'Halloran, J.W. Fyles, and C. Hamel. 1997. Seasonal changes of arbuscular mycorrhizal fungi as affected by tillage practices and fertilization: Hyphal density and mycorrhizal root colonization. Plant Soil 192:285-293.
Logan, K.A.B., R.J. Thomas, and J.A. Raven. 1999. Hidrogen ion production and ammonium uptake by two tropical forage grasses. J. Plant Nutr. 22:53-66.

López-Pedrosa, A., M. González-Guerrero, A. Valderas, C. Azcón-Aguilar, and N. Ferrol. 2006. GintAMT1 encodes a functional high-affinity ammonium transporter that is expressed in the extraradical mycelium of Glomus intraradices. Fungal Genet. Biol. 43:102-110.

Marschner, H. 1995. Mineral nutrition of higher plants. $2^{\text {nd }}$ ed. Academic Press, London, UK.

Martens, D. 2001. Nitrogen cycling under different soil management systems. Adv. Agron. 70:143-189.

Newman, E. 1966. A method of estimating the total lenght of root sample. J. Appl. Ecol. 3:139-145.

Oehl, F., E. Sieverding, P. Mäder, D. Dubois, K. Ineichen, T. Boller, and A. Wiemken. 2004. Impact of long-term conventional and organic farming on the diversity of arbuscular mycorrhizal fungi. Oecologia 138:574583.

Pfeffer, P.E., D.D. Doudds, G. Bécard, and Y. ShacharHill. 1999. Carbon uptake and the metabolism and transport of lipids in an arbuscular mycorrhiza. Plant Physiol. 120:587-598.

Phillips, J.M., and D.S. Hayman. 1970. Improved procedure for clearing roots and staining parasitic and vesicular-arbuscular mycorrhizal fungi for rapid assessment of infection. Trans. Brit. Mycol. Soc. 55:158-161.

Rubio, R., F. Borie, C. Schalchli, C. Castillo, and R. Azcón. 2003. Occurrence and effect of arbuscular mycorrhizal propagules in wheat as affected by the source and amount of phosphorus fertilizer and fungal inoculation. Appl. Soil Ecol. 23:245-255.

Tennant, D. 1975. A test of a modified line intersect method of measuring root length. J Ecol. 63:995-1001.

Vaast, P., and R.J. Zasoski. 1992. Effects of VAmycorrhizae and nitrogen sources on rhizosphere soil characteristics, growth and nutrient acquisition of coffee seedlings (Coffea arabica L.). Plant Soil 147:31-39.

Zadocks, J.C., T.T. Chang, and C.F. Konzak. 1974. A decimal code for the growth stages of cereals. Weed Res. 14:415-421.

Zunino, H., and F. Borie. 1985. Materia orgánica y procesos biológicos en suelos alofánicos. p. 434-490. In Tosso, J. (ed.) Suelos volcánicos de Chile. Instituto de Investigaciones Agropecuarias, Santiago, Chile 